\title{
'PUDUMAI' - INNOVATION AND INSTITUTIONAL CHURNING IN INDIA'S INFORMAL ECONOMY: a report from the field ${ }^{1}$
}

\author{
Barbara Harriss-White and Gilbert Rodrigo
}

(barbara.harriss-white@qeh.ox.ac.uk)

Paper for the conference on Innovation in India, University of Pennsylvania, November 13-15, 2013

http://www.southasia.ox.ac.uk/resources-greenhouse-gases-technology-and-jobs-indias-informaleconomy-case-rice

\section{CONTEXT}

Given the unfolding changes to global climate, established beyond reasonable doubt as anthropogenic in cause, a low carbon/low matter industrial and agricultural revolution is very urgently needed (Anderson, 2011). Since the 'silver bullets' of market mediated responses - cap and trade, and the clean development mechanism - have not yet shown any sign of reducing global GHG emissions, and since climate change is a very politically sensitive topic, the alternative - an approach of 'silver buckshot' - can only be a multitude of new, low $\mathrm{C}$ activities which have 'co-benefits' other than climate change as their objectives. $^{2}$ Co-benefits might be poverty reduction and/or an expansion of the size and quality of the labour force and/or the quality of work. ${ }^{3}$ Lowering $\mathrm{CO} 2-$ or other environmental benefits - would find political favour on these other grounds. India has formally adopted a co-benefits approach to climate change policy. ${ }^{4}$

\footnotetext{
${ }^{1}$ References are at present incomplete

22 Lohmann 2006; (Prins and Rayner, 2007 The wrong trousers; Hartwell Paper, 2010) .

${ }^{3}$ Dubash et al 2013, have used the co-benefit approach in a novel multi-criteria analysis of climate change policy for growth, inclusion and environment. (Dubash N, D Raghunandan, G Sant and A Sreenivas 2013 Indian Climate Change Policy: Exploring a Co-benefits Approach. Economic and Political Weekly June $1^{\text {st }}$ vol XLVIII pp 47-62

${ }^{4}$ Expert Group 2012 Low Carbon Strategies for Inclusive Growth, $12^{\text {th }}$ Five Year Plan, Planning Commission, citied in Dubash et al ,2013.
} 
Despite the fact that the informal economy accounts for about two thirds of GDP and $90 \%$ of employment ${ }^{5}$, the informal economy seems absent from almost all discussions of any kind of low-C revolution. ${ }^{6}$ Poor consumers are least responsible for GHGs, but many of the products of the formally registered and regulated industries which cause $70 \%$ India's pollution are retailed in the informal economy. ${ }^{7}$ So does it play such a negligible role in pollution as most people have assumed $?^{8}$ Another significant question is whether India's informal economy would be an obstacle to a low carbon revolution. Our wider research has tackled both these questions but it is the second question that provoked the exploratory project reported here. While the technological and organisational components of a low-C revolution have been modelled in scenarios, ${ }^{9}$ here we focus on the sector's own capacity to adopt the kind of technological and organisational changes that would be needed - in short to innovate. We ask whether and how innovation takes place in the informal economy.

The paper has three parts. We first introduce and try to clarify the complex and often 'fuzzy' structure of knowledge within which the question has to be answered. We then present the case material from our fieldwork, before welding it into an argument relating to the sets of ideas with which we start. An appendix of evidence may be found at http://www.southasia.ox.ac.uk/resourcesgreenhouse-gases-technology-and-jobs-indias-informal-economy-case-rice

\section{PART ONE}

\section{A UNIVERSE OF FUZZY CONCEPTS AND SUB-FIELDS}

\section{THE INFORMAL ECONOMY}

The term informal economy is a fuzzy concept with multiple interpretations and meanings (e.g. small / primitive activity; unlicensed / unregistered; untaxed; work without rights). Poverty and illiteracy reside in the informal economy. For

\footnotetext{
${ }^{5}$ While space is regulated: land titles are registered throughout India and forests are properties of the state, the agricultural and forest economies are officially part of the unorganised sector.

${ }^{6}$ One South Asian exception is Manchester university's research into climate change adaptation by low income groups in Bangladeshi cities.

${ }^{7}$ Iron and steel cement, aluminium, fertiliser, energy, paper pulp (CSE 2012)

${ }^{8}$ While all land-based agricultural activity and agro-industry is estimated at $45 \%$ of global GHGs, the proportion in the informal economy is not known.

${ }^{9}$ http://www.cccep.ac.uk/Research/Programmes/climate-change-mitigation/home.aspx; ref Tim Foxton.
} 
the most part, the informal economy also lies below the state's radar (Kanbur et al, 2012). ${ }^{10}$ Illegal activity evading the law overlaps with behaviour that preemptive the law, or which occurs in areas where regulations are not enforced or where they are neglected by the state. It overlaps with behaviour that doesn't come under the ambit of regulation at all, or that doesn't conform with it, or that developed prior to the imposition of regulation. . ${ }^{11}$

It is the relation of the economy to state regulation that makes informality particularly interesting. In relation to climate change, the informal sector is significant because the state cannot enforce policies in it; efforts to do so typically lead to extortion and police action and complicity but not to compliance.

India's informal economy is now linked directly through supply chains to consumption processes all over the globe, with all stages of a productiondistribution system weaving in and out of it. ${ }^{12}$ In addition, many if not most firms in the informal sector have aspects that are subject to regulation and some that are not: e.g. being licenced but not paying taxes or complying with labour laws or environmental standards. So, in the institutional matrix underpinning innovation, formal and informal are intertwined.

\section{INNOVATION}

In Lundvall's authoritative review of the concept (1992), innovation is also a fuzzy term, but at the core of its multiple meanings and strategic vagueness there is, at least, novelty. Innovation is an interactive process, generating not only new products but also new processes and technology, substituting new factors of production in an unaltered finished product capable of changing the

\footnotetext{
10 The National Policy on Urban Street Vendors 2009 has been analysed by Te Lintelo as a means of evicting them on phyto-sanitary grounds. The $11^{\text {th }}$ and $12^{\text {th }}$ Five Year Plans have sections on Inclusive Cities (focussing on sites for street vendors, housing for informal settlements, the integration of rag pickers into the municipal solid waste process chain etc. In Mumbai, planners are identifying specific zones for informal settlements and activity (Champaka, Pers. Comm., 2013).

${ }^{11}$ Labour, migration status, civil rights, tax, health and safety, land use, environmental damage are increasingly prominent theatres of informality in the so-called developed economies of the west (Larsen, 1992) J. Larsen 1992 inf illegality and enforcement Yale Law and Policy |Review

${ }^{12}$ Forty \% of India's manufactured exports are estimated to be produced there.
} 
social relations of work, e.g. through new labour requirements ${ }^{13}$ ). New forms of organisation (the organisation and institutionalisation of supply / exchange relations for the assembly of raw materials, the interactive processes of production and distribution, controls over finance, commodities and labour) are innovations. In new markets, two processes are at work, both of which involve innovation: i) invention to compete by reducing costs or to not compete by securing and defending a market share and ii) commodification, the conversion of things and activities into commodities in order that profit may be made from them. ${ }^{14}$ New activities can create further markets for the product or service and give rise to other multipliers through invention and commodification. ${ }^{15} \mathrm{New}$ kinds of persuasion create new forms of consumption and need. Kline and Resenberg in their (1986) overview of innovation also point out that improvements in the methods of innovation are themselves innovations, and to this we should add that the discarding of old practices is also distinctive part of the process of innovation, and one little examined in the literature. Innovation is often said to precede regulation (Dickson, 1988), from which it is a short step to argue both that innovators resist regulation and/or that regulation stifles innovation.

\section{NEWNESS/NOVELTY}

Innovation emphasises 'newness' but newness is itself also a repertoire of concepts. Schumpeter defined the innovator as an entrepreneur who invents new ways of linking factors of production. Invention is a process distinguished in two ways: on the one hand it differs from adoption / diffusion / 'transfer', and on the other hand it differs from adaptation, which fits a transfer to the circumstances of a local society and region and may involve pure invention along the way. Yet even adoption and transfer may involve unadulterated novelty, physical courage and unprecedented risk-taking as it diffuses to a new a region or social group (the retailing by a dalit of symbolically 'pure' milled rice in 1973 in Vellore being one such example).

\footnotetext{
${ }^{13}$ The labour processes themselves are often neglected by scholars of innovation

${ }^{14}$ http://www.opendemocracy.net/ourkingdom/colin-leys-barbara-harriss-white/commodificationessence-of-our-time

${ }^{15}$ Manufacturing and service provision in the informal economy have been recognised as continual, dynamic active processes with indirect multiplier effects ('indirect network effects') and formalinformal inter-connections throughout the system - from raw materials supplies, to final effective demand.
} 


\section{DEVELOPMENT}

Development is such a fuzzy term that textbooks are rare and encyclopaedias common. ${ }^{16}$ For Schumpeter development was a continuous process of innovation. The centre of gravity of the idea of development has shifted from industrialisation, state-building and citizenship and the sustaining of those excluded from the process, to the aid-driven 'war on poverty' and a set of dematerialised conceptions of human development and improvement in the human condition, spawning hundreds of thematic subfields along the way. Some recent interpretations of development, for example that of Paul Richards in his 1985 'Indigenous Agricultural Revolution', ${ }^{17}$ bear witness to Schumpeter, in conceiving development as embodying the constant adaptive innovations - in his case by West African farmers - and stress an indigenous capacity to innovate, unconfined to research institutes ${ }^{18}$. The relation between technology, work and employment, influentially invoked as a route out of poverty also stresses inappropriate technology transfer and the lack of indigeneity as being at the heart of the problem of slow development. ${ }^{19}$ Lant Prichett has provided a good analogy of how it is supposed to work in developing countries: entrepreneurship there is a matter of adopting transfers invented, developed and protected elsewhere. But the transfers of technology to DCs frequently fail when transferred to a new environment 'trees' are transferred without their organic 'roots'. In India the organic/institutional roots, certainly for livelihoods and the mass of the labour force, are in the informal economy.

\section{TECHNOLOGY}

Technology is as central to any response to climate change as it is to development, involving the social application of knowledge. But what knowledge, and applied to what part of society?

\footnotetext{
${ }^{16}$ Textbooks - Cowen and Shenton, Leys. Dictionary - Sachs, Encyclopaedias - Corbridge, Forsyth, Clark, Desai

${ }^{17} 1985$ Indigenous Agricultural Revolution: Ecology and Food Production in West Africa, Hutchinson

${ }^{18}$ See also Anil Gupta, 1999, Science, Sustainability and Social Purpose http://www.hks.harvard.edu/sustsci/ists/TWAS 0202/gupta 300199.pdf).

${ }^{19} \mathrm{~F}$ Stewart and $\mathrm{F}$ Shumacher. proviso that tech is appropriate for factor endowment and benefits resulting More notes from. Fitzgerald Heyer and Thorp Introduction in eds (FHT Overcoming the persistence of Poverty and Inequality pp1-18
} 
A major stream of science and technology literature ${ }^{20}$ is concerned with high tech frontiers and cutting edges - where human control over machinery/technology is often remote and mediated. This science and technology literature (SCITECHLIT) also makes the assumption that innovations happen in laboratories, with their distinctive social cultures ${ }^{21}$ (whether such labs are corporate, university or state institutions). They are then protected by property rights and developed and diffused with financial support, or learning by doing, and with further spill-over effects beyond the sphere to which they are first diffused ${ }^{22}$ Many questions arise when the conditions of this institutional scenario are relaxed. What are the factors really driving the choice of a production technique? What effect does the introduction of a technique have on production relations outside the immediate adoption process? How do the most efficient technologies in terms of competitiveness in global markets influence labour markets? Is this beneficial or detrimental to labour? What is the role of public policy institutions in this regard when it comes to the informal economy? $?^{23}$

\section{FIRMS AND SOCIO-TECHNICAL SYSTEMS}

Yet another subfield addresses these questions. Innovation through technological change is generally taken to be about firms responding to opportunities for which there is as yet either no demand or no supply, or neither. Yet firms cannot be understood solely in terms of markets and in isolation from non-market institutions due to i) externalities ii) the lumpiness and indivisibilities of innovation, iii) scale economies which need appropriate finance and iv) technological discontinuities which affect other firms (Roman, 2008). So the study of technical change needs to understand not only firms as institutions, but also their institutional 'ecosystem'. The disruptions due to innovation, especially the consequences of capital-biased technological transfers, may include 'public bads' which need to be regulated by public intervention (Dickson, 1988). But can we impose these conceptual frames onto the informal economy, and ask the same kinds of questions about the informal institutional preconditions of innovation?

\section{INNOVATION SYSTEMS}

\footnotetext{
${ }^{20}$ Another stream sees science and society as inseparable; a third deals normatively with the public outreach and engagement of science.

${ }^{21}$ Sunder Rajan , 2006, Biocapital

${ }^{22} \mathrm{Fu}, \mathrm{X}$. (2012) 'Foreign Direct Investment and Managerial Knowledge Spillovers'

${ }^{23}$ Vijaybaskar pers comm 2012
} 
Science and technology studies have developed the concept of an innovation system (IS): the public and private sector institutions and information needed for an innovation to be (commercially) developed and diffused. 'Agricultural innovation systems (AIS)' for instance 'are systems of individuals, organizations and enterprises that bring new products, processes and forms of organization into social and economic use to achieve food security, economic development and sustainable natural resource management'. ${ }^{24}$ The AIS includes a multitude of potential actors, such as producer organizations, research organizations, extension and advisory services, universities and educational bodies, governments and civil society organizations, co-coordinating bodies, individual farmers and farm labourers, and the private sector (including traders, processors, supermarkets etc.). ${ }^{25}$ This approach is useful because it allows for a great diversity of possibilities, consistent with real-world complexity.

For its proponents, what the concept of an Innovation System implies is that i) that if innovation can be a process as well as a product, the institutional matrix through which innovative knowledge and technology are created and transferred matters; ii) that the institutional matrix in innovation hotspots can be stylised into models of best practice ; iii) that this will involve a laboratory - > property rights -> scaling up diffusion; iv) that the creative act of innovation can be standardised and v) that deviations from best practice - 'innovation deficits'can be a) identified and b) filled. Empirical studies of IS are inherently transnational , comparative and macro-social: societies or companies with good innovation systems are then seen as able to leapfrog over long-drawn out / failed stages of lagged development.

But in our wider research [measuring costs, GHGs and human labour in the informal economy with a view to ascertaining alternatives as components of a new industrial revolution with low-carbon, decent-work co-benefits] there is no already-identified ground on which leapfrogging is to land, whether in ACs or

\footnotetext{
${ }^{24}$ http://agro-ecoinnovation.eu/wpcontent/uploads/2012/07/The role of knowledge in agro eco systems.pdf

${ }^{25}$ From: Global Forum on Agricultural Research <gfar-secretariat@fao.org> To: kassamamir <kassamamir@aol.com>

Sent: Fri, Jun 1, 2012 7:25 pm

Subject: [EGFAR newsletter] Agricultural Innovation Systems and Family Farming - An FAO E-mail Conference - June, 2012
} 
DCs. The idea of the innovation system has also come under convincing attack (Floysand and Jakobsen $2011^{26}$ ) for treating innovation as something purely technical when it is always a social and political process operating in what the authors call, with strategic vagueness, 'social fields'. 'Social fields', for Floysand and Jakobsen, are social sub- 'systems' at various (interacting) scales capable of generating social economic and political multipliers and requiring complementary institutional preconditions they call 'supermodularities' (i.e. packages of institutions) which can also include culture, the household, and institutions of work. While their case studies are in the formal economy of Scandinavia, in being expansive, the Floysand-Jakobsen approach is more useful than the orthodox IS, in which social structure is exogenous, for the context of an informal economy; although they completely neglect class relations.

\section{INDOVATION}

A new family of concepts provoked by the Bottom of the Pyramid (BoP) movement in corporate marketing ${ }^{27}$ appears to have addressed these questions. But appearances are deceptive. 'Indovation' is a concept meant to encapsulate the idea that (Indian) poverty leads to creativity. Although the relevance of this insight to the informal economy cannot be doubted, ${ }^{28}$ the examples invoked the Nano car, solar lights - are unfortunate in having origins far removed from the abode of the poor. Another concept is 'Jugaad', a North Indian word for a cost-cutting quick-fix, possibly unsafe, nearly always 'bending the law' or ignoring it completely. It is a peculiarly Indian contribution to the literature on 'Frugal Innovation', itself a powerful term which is focussed on (multinational) corporates. Its allure derives once more from its fuzziness. First, it celebrates least-cost ways to maximise profit. Second, this may at the same time involve an improvisatory and flexible approach to innovation (rejecting the research labs/innovation systems) and an exploration of the many sites inside a corporation where new ideas may originate. Third, further sites of frugal innovation include consumers themselves, normally regarded as 'the market' outside the organisation. In this literature the $\mathrm{BoP}$ is relabelled the poor,

\footnotetext{
${ }^{26}$ Fløysand, A. and Jakobsen, S.E. (2011): The complexity of innovation: a relational turn. Progress in Human Geography 35 (3),

328-344

${ }^{27}$ Though it is nothing new. Shampoo and soap were being retailed in sachets in periodic marketplaces in South India in the early 1970s.

${ }^{28}$ Its implicit romanticisation of poverty is another problem.
} 
marginalised and excluded, un-bankable, sick and disabled, ignorant and ageing consumer whose living conditions can be greatly improved by corporate innovations able to be paid for by them. ${ }^{29}$

The argument for the desirability of jugaad or frugal innovation is built up from case material and inductive generalisations. The cases selected in this literature are very distinctive - innovators are educated people capable of scaling up. The cases provide 'lessons', targeted at and driven by corporates. Now, while frugal innovation will certainly have an impact on the informal economy (in many instances formalising it), the entire family of concepts is geared to the business school, to a possible strategic option inside a big firm, rather than to the informal economy. We may indeed find frugal innovation in a literal sense in the informal economy but we must distinguish its application in selfemployment from the concept developed for the corporate sector.

\section{INNOVATION AND THE EXPANDED CONCEPT OF ENTERPRISE}

Nandini Gooptu and colleagues (2009; forthcoming) have taken the debate forward in finding that in contemporary India all kinds of agency are being considered as 'enterprising', with the connotation of being innovative,. Gooptu argues that the idea of enterprise is being generalised to an 'enterprise culture' in which innovation inside and outside work loses its original Schumpeterian meaning and acquires others appropriate to conforming as a subject to the totalising neo-liberal era. For an overeducated segment of the labour force even mundane work for a wage in a supermarket is relabelled as 'enterprise', carrying no implication of entrepreneurship in a Schumpeterian sense. A focus on wage work for corporates also ignores the explicit characteristic of the informal economy: self-employment. ${ }^{30}$ In the same way the idea promoted by some scholars that self-employment is 'good or better quality employment' (better than wage work), ${ }^{31}$ and that enterprise automatically includes innovation is a watered-down re-deployment of the concept of entrepreneurship which suffused the early Green Revolution literature of the 1970 s. ${ }^{32}$ In this literature the entrepreneur at best managed the risks of a small business and at worst was driven into self-employment by poverty and the lack of wage-work. To avoid

\footnotetext{
${ }^{29}$ See N Radjou, J Prabhu and S Ahuja 2012 Jugaad Innovation: a frugal and flexible approach to innovation for the $21^{\text {st }}$ century Random House

${ }^{30}$ The NCEUS is an expression of the ambiguity of 'enterprise' see Corbridge et al in British Academy book

${ }^{31}$ See for instance Sundaram in Corbridge et al in British Academy China-India book

${ }^{32}$ As in many publications from FAO's agricultural services division, itself a euphemism for trade in inputs and products.
} 
the circular conclusion that since self-employment is enterprise and the informal economy is dominated by self-employment, so it must be enterprising and innovative, enterprise as a loaded term must be deconstructed and used critically in explorations of innovation in the informal economy.

\section{INSIGHTS FROM OTHER WAYS OF KNOWING: THE CLASS STRUCTURE OF KNOWLEDGE AND INNOVATION}

From the critique of perspectives that view technologies and innovations in isolation from their social economic context, science and technology studies have scrupulously researched the social relations, work practices and discoveries of the labs. ${ }^{33}$ But anthropologists of work have also shown that innovation requires a bed of existing knowledge and practice, nowhere more so than in the informal economy. ${ }^{34}$ There are at least two aspects to it. First, technologies combine external tools and our 'internal tools' (body organs including our brains) in order to shape our environment. Brain-hand-foot-body co-ordination is a set of learned skills and a physiological state -which, as in hand-weaving, may require long periods of time to develop. The capacity to adapt to the physical rigours of practice is often built into apprenticeships and even less formalised processes of childhood learning and socialisation to work (Roman, 2008).

Second, innovation, even of a jugaad kind, does not happen out of the blue: existing knowledge resources feed innovation. Whether these resources / 'repertoires' are competitive bodies of knowledge or complementary ones, how they are kept secret or controlled or released publicly in the informal economy are all empirical questions. The implication for our understanding of innovation is that a systematic and embedded analytical approach to technology, product innovation and organisational change is needed. The relation between change and continuity in knowledge resources needs integrating into any analysis of innovation dynamics. Eric Ohlin Wright $(2012)^{35}$ distinguishes the various kinds of institutional churning into 'interstitial' versus 'ruptural' versus 'symbiotic change' interlocked in a pluralist arrangement of laws and social norms.

\footnotetext{
${ }^{33}$ Kaushik Sunder Rajan 2003 Biocapital

${ }^{34}$ Lave

${ }^{35}$ E Ohlin Wright 2012 Worker-owned Co-operatives DPRI, May $23^{\text {rd }}$, Oxford
} 
A political anthropological approach to innovation i) admits class and sees labour as well as capital as able to innovate; ii) sees innovation in every aspect of the production-distribution ecology; iii) explores multipliers and effects of innovation (both interstitial and ruptural); iv) acknowledges the continuity of the existing knowledge base as a vital precondition for innovation; v) regards the state which only indirectly regulates the informal economy as being vital for innovation, especially through its role in providing infrastructure and communications; and vi) finds a range of motivations for innovation (over and above the profit/ $\mathrm{CSR}^{36}$ / social enterprise motives of the mainstream literature). These often powerful motives include securing livelihoods, power (especially over labour), pleasure (reducing drudgery, satisfaction in skill) collegiality and political solidarity, altruism and nurture (Roman, forthcoming).

So the existing dynamics of informal innovation need understanding, because the next stages of development, or a response to climate change, will emerge from existing socio-technical configurations. If India's regulative structure is not to undergo radically disruptive change, a new 'green' industrial revolution / a low carbon transition would develop out (or in and out) of direct state control.

To sum up, we take from these knowledge fields the following ideas. While the basic unit of production, self-employment, is an enterprise, it is not to be supposed to be entrepreneurial or free of the coercions of poverty. However, while there are no research labs in the informal economy, this is not to deny the possibility of three kinds of innovation: invention, adaptive innovation and adoption or transfer in new circumstances. Innovation may happen as a product, a process or a technological repertoire throughout the institutions in which it occurs, including in derived markets such as transport; it may need protection and incentives to develop and diffuse. The labour force may innovate too, for it is a repository of knowledge that forms a crucible for innovation. While not directly regulated by the state, the informal economy is regulated by an institutional ecosystem, or socio-technical system, even generating hybrid institutions and practices combining both formally regulated and socially regulated behaviour.. But the identification of the most significant facilitating and obstructing institutions is an empirical question. So also is discovering the ways in which they act as incentives or disincentives. All forms of innovation

${ }^{36}$ Corporate social responsibility activity 
arise through the continuities of history and will have effects through spill-overs and multipliers which the method of field research must try to capture. Last but not least, to innovate means to destroy previous habits and products (one of many insights from Schumpeter) and their destruction is part of the process of innovation. People we interviewed didn't conceive the last aspect of innovation naturally as part of their accounts but it proved significant as we will see.

\section{PRACTICAL METHOD}

We returned in 2012 to a small town, Arni, in Northern Tamil Nadu that has been studied systematically, every 10 years from 1972 to the mid nineties and almost continuously though less systematically throughout the $21^{\text {st }}$ century nonetheless over a uniquely long 40 year period. It has grown from about 30,000 to well over 100,000 inhabitants as it receives rural-urban migrants and engulfs villages outside its formal boundary.

While there can be no representative town or local non-farm economy, this town has been accepted as a useful site in which to study rural-urban relations and local capitalism. (Nagaraj et al, 2004; Arisi, forthcoming; Srinivasan 2011; Basile, 2013). The town is used here as a historically specific case, but one which generates examples that we think are of wider relevance. Local more or less registered business associations have long had a crucial role in regulating the urban economy, representing sectors, negotiating particularistic interests with the government and controlling threats to their hegemony (Harriss, 1981). Presidents of Business Associations are elected as knowledgeable representatives and were also assumed able to tell stories that might be sensitive from a comfortable 'third person' perspective. We discussed change and innovation with them. ${ }^{37}$ Taking the population of 67 business and caste associations and major trade unions last studied in 1997 in this town (Basile and Harriss-White, 2000), we had resources to interview a randomly selected $40 \%$ of the presidents, along with a smaller number of office bearers of salaried workers unions - totalling $34 .^{38}$

We had with us a note in Tamil and English explaining our familiarity with the past of the town, the project's background and our exploratory purposes and

\footnotetext{
${ }^{37}$ Our questionnaire template is appended, though few interviews approached being complete.

${ }^{38}$ The population of business associations may have been expanded through the self-organisation of firms dealing in commodities new to the town since 1997.
} 
seeking verbal consent. We also had a template questionnaire (Appendix 1) which was learned by heart and never shown to respondents. In none of the interviews was the full set of questions completed - an expected and routine feature of this kind of fieldwork. Establishing rapport with busy businessmen requires allowing them to lead the encounter while the researcher attempts to structure it. The 'incomplete' method generates a data base like an un-finishable jigsaw puzzle which requires much imputation afterwards to use it for a regression-style analytical approach, but which more straightforwardly provides the elements for analytical profiling and narrative.

The response was unexpectedly positive. Several of the interviews were prepared for in advance by the presidents concerned, who organised groups of up to 10 people to meet us (electricians, teachers, transport and sanitary workers). These were not 'focus groups' but generated very wide- ranging and informative conversations 'outside the box'. So the total number of people to whom we talked about innovation and change was in the region of 75 . The fieldwork took a month with two researchers familiar with the region.

The narratives provide a series of snapshots and micro-histories. While they are not comprehensive, they proved much richer than anticipated (and too many to write up as case studies). This very richness has generated a problem for analysis, since a book-length treatment - the method of 'Jugaad Innovation' for instance - is impracticable Instances of novelty and innovation have been rearranged and listed by type and themes. ${ }^{39} \mathrm{We}$ then did a content analysis to establish an account which stresses relations, institutions and processes, rather than quantitative generalisations, - leading to conclusions which engage with the ideas that provoked the research questions in the first place. We also absorb quotations into the narrative as illustrative of the claims and comments that men (and some women) in Arni make as they struggle to make sense of their contemporary conditions.

Does the informal economy innovate? If so, what kinds of innovations emerge from non-formal institutions?

\section{PART TWO:}

\footnotetext{
${ }^{39}$ See the Appendix at http://www.southasia.ox.ac.uk/resources-greenhouse-gases-technology-andjobs-indias-informal-economy-case-rice
} 


\section{THE TOWN}

'Arni is not a poor town'. 'Arni's economy is in good shape.' (President of Arni's Chamber of Commerce, June, 2012)

Though we have argued that Arni is a useful site, it is a particular settlement with its own distinctive history.

THE SPATIAL ARRANGEMENT OF THE ECONOMY - Economic power in Arni has been reconfigured and relocated a number of times since Independence. Then, the heart of the bazaar was located in what is now an impassably narrow, pig and rat-infested side street, just wide enough for a single van. The weekly market site near the old centre no longer exists, having been transformed into a bus-stand. Its former regional role in the marketing of cattle has also disappeared with the replacement of animal traction by fossil fuel (Gathorne-Hardy, 2013). The pre-Independence site of the town is still the heart of the congested informal business economy. To the west, the by-pass to this throbbing heart, incongruously named Gandhi Market Road where statues of the Mahatma and Ambedkar vie for public space, there is now a post-1960s central business district, but in 2011 the road was reinforced and widened and a motorway style central barrier erected to prevent customers from crossing. The wide, earth verges, which used to accommodate lines of cycles, motorbikes and squatter-stalls, have been tarmacked over for traffic, making them all very difficult to park on the now narrow metalled verges. Though it is often filthy, the town is not run-down. New residential quarters sprawl further west, while the relatively neat silk quarter, a product of the 50s and 60s, occupies the south of the town. There, dyeing, spinning, weaving and marketing compete for space with residential housing. Rice go-downs [warehouses] used to line a number of streets in the heart of town but are now located on the periphery where their owners profit from lower land values/rent. A new by-pass encircling the entire town is rapidly becoming a 'ring of steel' for fully automatic rice mills. North of the bypass, but umbilically connected to the town through roads and transport, residential demand and low-order service jobs, a huge tract of agricultural land has been turned into a private higher education cluster by a single investor - the former AIADMK MLA and MP.

ECONOMY- The town's economic base has been agricultural marketing, general retail, energy retail, and administration, together with a small industrial district for silk handloom weaving and a cluster of goldsmiths and pawnbrokers. 
Now the bazaar economy of more or less independent small family businesses is being threatened by a new scale of sub-national and national capital, currently with branch firms and agents for sectors such as cement, dairy products, fueloil. For the future there is also the perceived threat of supermarkets.

The town's engagement with the global economy is at best indirect. It is linked through the export of silk products to S.E. Asia, brokered by wholesale firms in Chennai (some silk material now even reaches China, from where until recently the raw material was imported); the export of fodder from rice mill byeproducts (via Chennai to Europe); and the import of clothing and laminated wooden computer-furniture. Arni is being globalised by pre-emptive responses to threats, rumours and images, rather than by the active intervention of global supply chains. The latter are sited nearby. Every day vehicles from Nokia and other factories on the Chennai-Bangalore corridor to the north east and from the leather export factories around Vellore to the north west scoop up a (semi)educated labour force from the town and its hinterland - enabling it to commute quite long distances for work.

POLITICS- After the North Arcot District was split in two in 1990, Arni became even more remote from the new (Tiruvannamalai) district HQ than it had been from Vellore before. Its positioning then disadvantaged it in post 1990 district politics. Before 1990 the ruling party MLA in Cheyyar to the east had exercised such a powerful patronage (courts, colleges etc) on behalf of that much smaller town that Arni was politically emasculated. Meanwhile Arni's own MLA accumulated land for private purposes. It is reported locally that outrage and shame at the national $2 \mathrm{G}$ scam which broke in 2011-12, implicating Tamil Nadu's then ruling political elite, propelled Arni voters further into the oppositional wilderness through their support for the minor DMDK party of actor Vijay Kant. 'Now', said a cynic in 2012 'Arni is better taxed but there is no quid pro quo'. Cutting tax evasion is one way the state keeps an eye on the informal economy.

\section{FORMS OF $21^{\text {st }}$ CENTURY INNOVATION IN ARNI'S INFORMAL ECONOMY}


There is no scholarly consensus over the typology of innovation. In the separate appendix ${ }^{40}$ we have summarised the innovations described by our respondents. Here our analytical narrative focuses on examples which we judge most richly illustrate the political economy of innovation in the informal economy.

\section{SCHUMPETERIAN INVENTION -}

Three examples are captured in the field survey (under-specification while 'maintaining safety' in reinforced concrete; site design in rice mills; and phase change by electricians, which is explored here). From only 85 in 2000, the town's electrician workforce has grown to about 730, 320 of whom are registered; only 20 of these have any formal qualification, some of the rest having inherited licences from their relatives. The association has started to issue certificates based on experience. Most electricians are self-styled as 'under-educated' and low-caste village men who learn as a 'hand' on the job while they work for self-employed seniors, all of whom are keen to experiment. Being an electrician is a physically dangerous occupation and the association for registered electricians has a strong esprit de corps. 'The work we do is not illegal but it is informal' explained the president of Arni's electricians' sangam.' Vague about the date of the invention, but faced with a chronic inadequate and unreliable supply of electrical power for irrigation pump-sets, and a constant demand for repairs to breakdowns, Arni's electricians have succeeded in modifying 3 phase technology for 2 phase power supply. ${ }^{41}$ This enables pumpsets to ride oscillations in power rather than break down. ${ }^{42}$

This innovation involves adapting a condenser (a device to store energy and to release it in spurts) by switching fuses. The TN Electricity Board standard for capacitators is high but local power consumers use poor-quality sub-standard models so the 3-2 switch aids efficiency. In 2012 it cost Rs 600-1000 to purchase and install, and is reckoned to last 2-5 years. Electricians continue to work on new ways of compensating for irregular power through battery inverters (coping with a sudden total power cut, or one phase being down), voltage stabilisation, and what is known as power factor correction.

\footnotetext{
${ }^{40}$ http://www.southasia.ox.ac.uk/resources-greenhouse-gases-technology-and-jobs-indias-informaleconomy-case-rice

${ }^{41}$ Three phase electricity comes in three separate streams (for which three separate wires are needed) designed to oscillate in sequence to generate power.

${ }^{42}$ This is not to argue that this invention does not exist elsewhere but the Arni electricians do not know of a parallel invention. See Shah and Verma 2008 Co-management of electricity and groundwater EPW for a similar case in Gujarat.
} 
There is some dispute about the inventor ('was it Anandan or Annamalai'?) but as invention yields no innovation rents, individual entrepreneurship is not as important as the invention. Electricians describe themselves as 'open' and constantly learning and passing on knowledge. They experiment on the job. (For an example at one extreme a bottled cowdung paste to help motors start with two-phase power; and at the other an exploration of borders between electricals and electronics: using electronics to operate small power generators by remote control.) The risk of on-site experiments is explained to the 'owner' on whose equipment the work takes place. 'If experiments fail, we repair the failure' said an unregistered electrician.

It was independently corroborated that the Arni invention has been formally scaled-up and developed with an automatic switch application that is being mass-produced by a Bangalore engineering firm - 'after consulting' Arni electricians. Not to be outdone, the electricians are adapting the mass product further.

In sum: a growth in numbers together with increasing informalisation (lack of registration) both co-exist in this case with informal formalisation (certification). The state's own inability to enforce standards in supplies, in its own utilities, or in consumers' appliances, creates economic problems that have generated entrepreneurial responses. Property rights are irrelevant to the local development and diffusion stage, but scaling up has been achieved through free transfer and private appropriation by a company with access to finance and marketing. A combination of the trade association and customers' appliances is the informal equivalent of the research lab, and a continual interaction between formal firm and informal labour enables diffusion (albeit with large difference between the two in the returns to work).

\section{ADAPTIVE INNOVATION}

Four cases are recorded in Appendix 2. Tucked away on an upper floor of a poorly constructed building in a narrow alley is a 'computer centre' established in 2010 in which innovations have been cleverly adapted to the local economy and society. The 'centre' - a room with a balcony - is collectively owned in a complex way by 5 young graduates, two of whom manage the Arni centre for the other micro-investors. They work part-time there and part time in salaried work in another town at some distance, since otherwise it would not break even. Its stated objective is 'software training'. A three-month course in the 
rudiments of computer-aided design (CAD) and 3-D design is the basis for which certificates are issued from the 'centre'. The clientele are village-based and too poor to pay the Rs 3,000 fee as a lump-sum. So the introduction of instalment payment has increased the centre's social reach. And there is a social benefit: through this training, 'customers' schooled in Tamil are forced to acquire 'screen' street wisdom in English.

This is a novel adaptive organisational response to lack of adequate capital or adequate demand in which formal educational skills are being diffused to the informal Tamil-language economy in return for an informal formalisation through certification.

In the ring of 40 licensed automated rice mills ${ }^{43}$ which started to hug the bypass in 2010, many adaptive innovations have taken place - over and above site design by local freelance engineers. New parboiling processes without stench create a new type of rice that is lightly parboiled for middle class consumers. A new post-harvest process has transformed a commodity - rice - into a new category of 'processed food'. A quantum leap in capacity (each mill processing as much as the entire town processed annually in the early 1980s) has required a quantum leap in long-distance year-wise scoping of raw material which has in turn segmented the local paddy market. The new mega oligopolists source most of their supplies from outside the region, while the smaller and older Modern Rice Mills tend to source locally.

These automatic rice mills are formally licensed but otherwise unregulated. Despite their scale, they are not necessarily a revolutionary and ruptural innovation since it is not yet clear whether they reduce costs of production. The branding of 'new' types of process may yet create consumer demand for a costlier product and vindicate automation. The' ring of steel' drives differentiating exchange relations in the local rice economy but the possibility that many independent individual decisions may result in collective overcapacity cannot be ruled out.

\section{ADOPTION}

Adoption is by far the commonest route to innovation. It is what local people understand as innovation, and the rest of the discussion of field material is devoted to the derivative spread of technologies, products and practices

${ }^{43}$ Rs 3-4crore each - £750k-£1m 
developed elsewhere. This is nothing new: the Green Revolution epitomised development in the form of continuous innovation-adoption and creative destruction. ${ }^{44}$ In the non-agricultural economy, formerly un-commodified or semi-craft commodities or practices have continuously disappeared, to be replaced by new mass-produced commodities (crushed sea shells by paints / turmeric by cosmetics / dhobi services by dry cleaning / the barber by sound services (for barbers are musicians too) / open defecation - to some extent - by sanitary-ware). On a micro scale this process has combined capital bias with caste continuity resulting in economic differentiation within castes. But what our 2012 field evidence recorded is happening at a revolutionary scale, at a pace and with a scope never before encountered.

\section{THE ADOPTION OF NEW PROCESS TECHNOLOGY}

We were given six examples. One Arni tailor pioneered electrically-powered sewing machines from China (through Chennai) at $2 / 3$ the cost of Indian 'power' machines but with ambivalent outcomes. Positive: the tailor not only increased the competitive productivity of his own firm but established a new agency and many machines were sold initially. Negative: despite productivity advantages, due to the erratic and fluctuating electricity supply power, machines are being abandoned in a technological reversion to manual sewing machines.

This case emphasises the importance of infrastructure for competition through process innovation in the informal economy. Infrastructure is also found to be constraining innovation through the commodification of processes - for instance in the case of deep freezer-cold chains for industrially processed milk products.

\section{THE ADOPTION OF NEW PRODUCTS}

We discuss three from a large set of examples here. The first is the transformation of the nature, quality and symbolic meaning of basic food (exemplified by the very rapid rise in high quality parboiled rice marketed, not only to the metropolis but also locally, for nutritional and health benefits). Whereas high quality rice was sold raw in the past for the highest status clientele, by 2012 only $2 \%$ of all rice was estimated to be un-parboiled. A similar example is new sources of cooking oil generally endorsed and specifically prescribed by medical doctors: e.g. sunflower oil 'for cholesterol',

\footnotetext{
${ }^{44}$ Harriss, 1971
} 
while new palmolene oil is being sold to informal petty street vendors for 'healthy' deep frying of snack foods. It is left to individual reputation, rather than state inspection, to assure the quality and healthy properties of these Tamil 'fast foods'. The long-standing association between properties of food and health (hot and cold, pure and impure, vegetarian and non-veg) has long been being replaced by modern medical reasoning in which science is yoked to advertising. And now this is pervading the informal food economy of Arni.

A second example of new products is alcohol. From 10 outlets in 2000 to over 100 in 2012. Sales are formally heavily 'regulated' but in practice the state fails to prevent large scale dilution, or black market sales of alcohol hoarded from weekdays for out of hours sales on closing day. Among spirits, arrack has disappeared, substituted for by brandy, whisky and rum in 'Bottom of the Pyramid' bottles of $150 \mathrm{ml}$.

Third, but by far the most important, is the banking revolution. After an invasion of both nationalised and private banks and ATMs unleashed between 2007 and $2009,{ }^{45}$ transactions that used to be personalised and reimbursed with asymmetrical lags - which force higher working capital requirements on the weaker party ${ }^{46}$ - have been very rapidly replaced since 2010 by almost instantaneous transactions using 'NEFT' (the National Electronic Fund Transfer) technology. NEFT vastly reduces transactions costs, and depersonalises market exchange. It combines with the replacement of family labour by informal wage workers (reported later - which destroys trust relationships between owners and consumers) to destroy sales on credit. A few shops selling lower quality equipment to a poorer clientele continue to attract custom with credit and instalment-repayment.

Private and public banking technology requires licensing to create accounts and title deeds to access loans. It is a powerful incentive for a formalisation confined to these eligibility criteria. But it is inevitably accompanied by further informalisation. Informal innovation using bank loans may be benign (takeaway food from 'meals hotels') but not necessarily so (adulteration). Formal innovation may destroy informal commodity economy (the disappearance of toddy and arrack production).

\footnotetext{
${ }^{45}$ After the retreat of rural banking during early liberalisation

${ }^{46}$ BHW Credit, finance and contractual synchrony in a South Indian Market Town' in (eds) I Guerin, S. Morvant and M. Villareal, Microfinance, debt and overindebtedness. Juggling with money. (OUP New Delhi)
} 


\section{THE CREATION OF NEW MARKETS}

We were given many examples. ${ }^{47}$ Handloom silk and the re-branding of the town: Threatened with extinction by power loom competition, the local handloom industry has reorganised itself spatially and has merged brands. Arni sarees have been rebranded as 'Made in Kancheepuram'. The cost of production of these 'Kanchee sarees' is much lower when outsourced to Arni. ${ }^{48}$ In turn, Arni is outsourcing its inferior brand to Salem. The outcome is a huge local revival in informal craft silk production, the only limit to firm size being the supply of skilled supervisors of artisan production. The quality of Arni's production has improved. Returns to weaving have increased. From 2007 to 2012, the industry increased by $50 \%$ to 300 firms and its structure concentrated. It is dominated by an oligopoly of 10 big firms, making ever closer links with Chennai-based exporters. A new buyer-governed supply chain is emerging in which export markets in Europe, S.E.Asia and the USA drive design alongside more supplier-governed production for domestic demand at weddings and festivals (such as Deepawali and Pongal).

Even in the informal economy of weaving, the manufacture of image is vital to marketing and so to production. In this case relabeling has had a significant impact on process, product and sources of innovation.

\section{NEW SITES}

In a forthcoming paper Guerin argues that change in local economies is driven by the specific social configurations of sites, and that small towns are increasingly attractive sites for investment due to improvements in the quality of the labour force, which are in turn the result of education and the relative quality of the public health environment. ${ }^{49}$ From our field research we have reason to doubt that education attracts inward investment to Arni, so much as outward migration, and the public health environment is increasingly hazardous, but within the town site definitely matters. Lefebvre reminds us that site is a

\footnotetext{
${ }^{47}$ See the appendix at http://www.southasia.ox.ac.uk/resources-greenhouse-gases-technology-andjobs-indias-informal-economy-case-rice

${ }^{48}$ Arni weavers can make Rs 2 lakh sarees in a fortnight (for which they might earn Rs 25k). ( $A$ lakh is $100,000)$. The conditions of Arni's silk labour market which enable weavers to be paid less need further investigation.

${ }^{49}$ Guerin I forthcoming Labour in Contemporary South India in (eds) Harriss-White and Heyer Indian Capitalism in Development, Routledge
} 
socially constructed aspect of production and reproduction relations, mapped onto space. ${ }^{50}$ What is innovative about site in this small town? First, the $21^{\text {st }}$ century has seen the consolidation of a new bourgeois residential quarter at one remove from the congested centre, a western suburb resembling that of TV advertisements - spacious and well laid-out, but built by unregistered masons and builders with informal quality inspection. In response, the high-rent central town is being demolished plot by plot, with multi-storeyed cement houses and mini-malls replacing the single storey tiled, courtyard houses, again built by informally qualified workers. And over and above the new residential lay-out and the new sites of production around the ring road and in the regulated market new forms of regulated consumption practice bypass the local town altogether. Local elites use the district HQ, Tiruvannamalai, and Chennai for higher-order consumer durables and leisure activity.

Wealth, spatial reach and the formally regulated economy appear to converge. In fact they all rest on infrastructure and construction industries based heavily on informal labour and informal relations of raw material supply.

\section{NEW WAYS OF KNOWING}

In the $21^{\text {st }}$ century, the means of knowledge about innovation in products and processes has developed from word of mouth (pump-sets), cards and pamphlets (groceries) to i) TV, Fairs, Internet - about supply and demand as far away as China (wooden furniture, ready-made clothes, silk); and ii) Advertisements with their dual roles of information and ensnaring loyalty have been newly localised in many ways. For one example, mill brands for rice: whereas 10 years ago the town itself was used to brand rice (e.g. Arni Airplane Rice), now a single mill may use three separate own-brands for different social destinations. In another case, groceries, branding is reproduced at micro level. Using family labour at weekends, owners have started to package dry food in plastic, complete with improvised expiry dates. Branded plastic shopping bags are also the mandatory replacement for durable cloth bags. In a third example, tailored clothing, brands are now advertised on the outside of clothes rather than inside as formerly. They are also not optional. Arni is part of the logo-turn: the medium is the message.

\footnotetext{
${ }^{50}$ Lefebvre, H. (1991) The Production of Space, Oxford: Blackwell
} 
In some sectors incentives for informal innovation have even been introduced: the Tailors Association president has a fund for incentives and regular prizes are offered for best new practices developed in the town or imported from outside.

Visions of change in the media and threats of change in formal legal regulation trigger imitative informal innovation.

\section{NEW EXCHANGE RELATIONS}

The role of the banking sector's payment revolution, described above, has been of paramount importance in the destruction of personalised exchange, with widespread ramifications. One ramification is its role (amid the proliferation of new informal financial institutions (Polzin 2007, forthcoming)) in the emergence of the Regulated Market site for grain transactions, after decades of marketed surplus avoiding it due to production debts that were repaid in kind at sites specified by the trader-lender. The first transaction between producer and trader is now formalised though the open auction of paddy. A new registered and organised labour force works there too. Informal aggregators - lending to, and bulking up the small surpluses of marginal farmers - have found niches there in which they pass themselves off as primary producers. A second ramification of new exchange possibilities is the facilitating of pan-Indian supplies in groceries and foods, and international flows in textiles - all brokered through known intermediaries but from unknown suppliers, and using NEFT bank transfers. The removal of trade restriction on bank loans has permitted new scales of finance for working capital: e.g. 'a crore in a store' ${ }^{51}$ for rice mills, some of which are insuring their stocks for the first time. But the commonest new element in the bazaar is new models of price formation: out with haggling (for old irrigation ironware, for example); in with fixed prices associated with branding and packaging, even for activities not regulated by the state (unregulated new hardware and interior decoration, state-regulated agrochemicals and pharmaceuticals).

New technology and an expanded role for banking enable a new scale of formally regulated exchange relations. But these leave niches for informal business. $^{52}$

\section{ADOPTIVE INNOVATION IN LABOUR PROCESSES}

\footnotetext{
${ }^{51} \mathrm{~A}$ crore is $10,000,000$

${ }^{52}$ Theorised by Michel Crozier
} 
In her study of Arni's silk industry, Camilla Roman (2008) discovered the capacity of the skilled but informal labour force to be innovative. She also stressed the continuity of the workforce's information base, in which their small-scale but disruptive innovations are nurtured. In addition, she traced how innovation has consequences for the labour force. Here we order our discussion of innovation by distinguishing these different theatres of agency and innovation.

\section{AGENCY AND INNOVATION BY LABOUR}

Notable $21^{\text {st }}$ century changes in workforce agency involve two-way flows of labour (lagging by at least a decade the caste-stratified two-way flows of capital of the 1990s). ${ }^{53}$ In-migrating labour from Orissa finds ' 6 -month' niches in the labour forces of rice mills and meals hotels (the latter providing language training for migrants while they work under constant supervision). ${ }^{54}$ Meanwhile educated labour out-migrates to the Chennai-Bangalore corridor ('There is more to life than Arni') while uneducated labour flocks in gangs to the brick kilns and construction sites of the metropoles. Elite children are forced to migrate long distances to be incarcerated in private English language boarding schools. ${ }^{55}$ The local workforce has also been reconfigured by activity and site with the entry of women. There is a massive increase in outsourcing and homeworking in Arni, with women becoming specialist tailors for women's clothes, for instance. The genders are integrated into the market, then subject to a change in industrial structure and then segregated. ${ }^{\mathbf{5 6}}$

A second aspect of the agency of Arni's informal labour force -its innovation in the labour process - and the response of its employers is change in apprenticeships and increased 'entrepreneurial hurry'. For tailors, the training is long - boys start with the sewing of buttons and the stitching of holes and progress by hand and machine over 3 years. Of late the balance between the demand for and supply of apprentices has been disturbed by the existence of alternatives for better-educated boys and men, resulting in. an acute shortage of

\footnotetext{
${ }^{53}$ BHW and Janakarajan 2004 Rural India facing the $21^{\text {st }}$ Century Anthem

${ }^{54}$ In 2012 there were over 100 in Arni. Recruited through contractors in Madurai, Chennai and Coimbatore. The migrant labour force is housed by employers without other perqs or rights and employed for 6 month stints i.e. two shifts a year. Wages are paid directly to the migrant who deals with contractor. 'Management pays' if labour is sick. Though migrants are normally thought to be paid less, wages to migrants are higher than to local workers because migrants are on call 24/7/30. ${ }^{55}$ In towns not dissimilar to Arni such as Erode, Salem, Tiruchangode, Uthangarai, Namakkal where private schools have been extensively advertised on TV.

${ }^{56}$ Cf Sneha Krishnan D Phil
} 
male tailoring labour. Market incentives have resulted in incomplete apprenticeships becoming the norm - with the result that informal tailors are constantly threatened with undercutting from apprentices who abscond and set up on their own. Supply no longer matches demand and the outcomes have been dramatic. First a slowing of the velocity of production (from 2 hour shirts ('made while you visit the cinema') in 2005 to 20 days in 2012). Second, strong incentives are accidentally created for the expansion of ready-made clothing. Third, the entry of women brings a gender differentiation which intensifies with the segmentation of work. Women emerge from their homes to acquire new kinds of learning, not through apprenticeships but in informal training institutes. Several of these have been founded recently in Arni: one trains as many as 60 women at a time. Female tailors then lobby, through an un-registered union, for 'certificates' from the business association. Similar kinds of repercussion or 'spill-over effect' have been reported for electricians and construction workers. Long-employed in the public domains of the local state and in teaching, the entry of educated girls and women ${ }^{57}$ into the local commercial workforce and market-place is an ambivalent process because the available local work is not necessarily commensurate with their qualifications (e.g. general retail sales, cool drinks, ready-mades, sweets and bakery work at Rs 150/day).

The unprecedentedly massive exercise of agency on the part of semi-skilled and skilled labour has produced innovation in the informal labour process. Employers have had to support this via certification and further innovation (language training), as well as via increased surveillance (of migrant labour).

Camilla Roman (2008) has reported innovation, as opposed to agency, by labour in craft weaving, especially improvements in design. She sees it resulting from the continuity of technological knowledge, through informal onthe-job training, lived experience and experimentation. Developmental adaptations to looms are also said to be driven by the desire for reduced physical effort and lower physical risks (though these are often traded off against each other), and the existence nearby of related professional skills/ complementary knowledge (such as computer aided design (CAD).

It is as much by the innovative behaviour of the craft-producing work-force as by the branding entrepreneurship of employers that the threat to the industrial

${ }^{57}$ Cf Gooptu 2009 and CWM research in our project - Mani, Mody and Sukumar 2013. 
district for handloom weaving (at its peak involving thousands of looms) has been turned into a stimulus.

\section{AGENCY AND INNOVATION BY EMPLOYERS FOR LABOUR}

Employers routinely respond in locally innovative ways to demand - pulls (socially constructed through investments in information and through advertising). In their adoptive/ innovative responses, many factors play roles: the existence nearby of technology and complementary technology (silk), networks of contacts with shared repertoires of understanding (through commerce and through the business associations), loyalty in the labour force (lack of which slows up construction projects), the availability of working capital and investment loans ( resulting from the banking revolution), and returns which compensate for un-revolutionary increased costs of production for transformed and processed products (food). ${ }^{58}$

Changes in the class-structured knowledge base for innovation. The social origins and competences of the local capitalist class are changing. Rice mill innovation no longer requires a background in agriculture, as it did in earlier decades, but instead, in one example, has been based on a background in engineering, steel (metal rods retail) and electricals. As observed for electricians at the start, collegiality is more common than protective secrecy among innovators. Operators of FAMRMs ${ }^{59}$ in Karnataka allow Arni's local engineers to view their sites and machinery - and even train Arni's skilled labour.

At the demand of labour: Local business associations have been under pressure from workers informally to formalise apprenticeships. The electricians, for instance, have developed a new and informal hierarchy of certificates after various lengths of experience and some exams. This makes it possible for electricians to find work on grounds other than personal recommendation. A similar system of qualification as a precursor to self-employment and outmigration is found in the construction industry. Arni is an informal training

\footnotetext{
${ }^{58}$ Roman (2008), for silk also noted that the capacity to introduce discontinuities depended upon ties of kinship, of fictive kinship, of spatiality, of commensality, shared social functions, and the regulative experience of business associations.

${ }^{59}$ Fully automatic modern rice mills
} 
ground but as one engineer told us 'It means the construction workforce is constantly learning and constantly changing'.

The division of low-skilled labour is becoming increasingly specialised. 'Jobs are classified' said a builder. In the construction industry, the following tasks are recognised as needing distinctive skills: foundation labour; masonry; concrete labour; centring labour; steel fabrication labour; carpentry; transport; plumbing. Contradictory processes of wage work are developing inside the town. On the one hand the urban economy is undergoing an explosion of selfemployment using the skills of the contemporary economy ${ }^{60}$, but on the other the biggest companies (engineering, mills, etc) are gradually integrating formerly self-employed workers into their paid wage-labour force.

Labour Displacement: Changes in post-harvest processing and rice mill automation generate massive labour displacement and masculinisation employers seems to have an active dislike of low-caste unskilled and female labour. Before full automation a mill with the capacity of a FAMRM ${ }^{61}$ would employ 50 women and 30 men $^{62}$. With full automation, there are just 5 women and 12 men.

Innovation in the labour process by employers of labour often involves further scales of commodification of the technologies and processes of production. For this level of sophistication, a social background unconnected with agriculture or the local rural economy is often necessary. Process commodification creates new elements in the structure of prices. New levels of complexity in the labour market involve contradictory as well as complementary social processes: specialisation, the vertical integration of labour skills, self-employment and labour displacement. Local employers also concede demands for the 'informal formalisation' of labour force skills which they know will lead to reduced dependence of workers on them, the depersonalisation of market transactions, and in the case of men, migration out of Arni.

\section{CHANGES IN THE ORGANISATION OF FAMILY BUSINESSES}

'Men don't want to work for others'. 'Self-employment is an aspirational state' (President of the Tailors)

\footnotetext{
${ }^{60}$ E.g. electricians from 85 in2000 to 730 in 2012.

${ }^{61}$ Fully automatic modern rice mill

${ }^{62}$ While women would work on the sun-drying yard, half the men would work in management and engineering ('staff') while half casual for unloading and loading and parboiling.
} 
Under the Indian constitution the private sphere, the family, is regulated by customary law derived from a plurality of religions. It is then contrasted with the relative secularity of the state-regulated public sphere. But in selfemployment and in the family firm the private meets the public. The customarily regulated family is the building block of the economy. Informality is hard-wired into it.

In Arni there has been a massive expansion of small firms which are run by under-educated self-employed people. They are associated with many of the process and product innovations described above e.g. the electricians who have grown from 85 in 2000 to 730 in 2012, or pumpset retail and repair mechanics who have increased from 10 shops to70. The new skills needed for such work (e.g. boring for tube-wells) are 'learned by doing'. Throughout India this expansion of modern artisanal activity is an uncelebrated feature of liberalisation. ${ }^{63}$

At the same time firms undergo specialisation and complexification, Even tailoring has reorganised itself to handle demand, through a gendered 'vertical integration' on a micro scale, with separate 'firms' specialising in repairing cutting, sewing and pressing.

Family business is being re-organised in a ruptural change: In the central 'bazaar' (that hosted the dominant forms of market trade and jobs in the modern economy of the 1970s) the mass exit of the educated younger generation to salaried jobs in nearby IT, electronics and auto industries is causing a decline in family labour. This is compensated for by an increase in wage labour. 'Only scions with ' business level education' (low) stay in the bazaar economy - it's hard work - long hours - competition - no holidays - with the further problems of apprenticeships' a pump-set dealer told us. The entry of wage labour into tiny firms reinforces the shift in the 'crafts and craftiness' of the bazaar in which trust-based haggling over price, credit and debt is replaced by norms.

STASIS AND DESTRUCTION WITHIN THE FLUX IN

\section{LIVELIHOODS}

In this account of innovation and change, the case of dalits is striking in contrast. We interviewed the representatives of marketplace porters, transport workers, fruit and vegetable sellers and sanitary work, activities dominated by

\footnotetext{
${ }^{63}$ Bhw 2012 Capitalism and the Common Man Agrarian South
} 
dalits. The contrast between their current work conditions and their aspirations for their children is also very marked.

The erosion of caste exclusivity works perversely for sanitary workers, permitting a new downwards status mobility, while reducing work opportunities for dalits. Between 6 to 8 non SCs have entered Arni's state controlled sanitary workforce who clean streets, drains and latrines. They are all socially disadvantaged: Naidus and Mudaliars without any education, or 'people in cross caste marriages' (a stigmatised novelty), or the widow of a low level government employee given work on compassionate grounds. Here and elsewhere the deliberate lack of change is a technique of labour force control, actively preventing emancipation in the labour force.

Low caste and dalit market-place loaders are controlled differently, having had no wage re-negotiation for five years despite inflation; their wage 'after liquor' is equal to that of agricultural labour. Sources of demand for their work have shifted location: bulk lorries bypass the centre of town, and factories on the periphery develop their own loading labour force. They have been undercut and their territory informally encroached upon by ethnically networked casual labour from Sri Lankan refugees whose desperation doubles the supply of loaders. As a result, work and rates and gang sizes are shrinking and the organisation of labour is on the defensive. Divided by team and village of origin, the Loaders' Union is weak.

Extinction: The negative experience of complete destruction of labour practices was difficult to elicit from Association presidents. Child labour has been reported to be on the increase in some parts of India, ${ }^{64}$ but the opposite is widely reported to hold for Arni. The Rotary Society president reported 'no child labour'. The teachers spoke of 'a few truants in the bazaar', unknown to their parents, as well as of child migrants who have gone from Arni to 'Salem and Bihar' for brick kiln and construction work. Arni's tailors now have a strict rule not to take child labour in the interests of children's education (a practice also noted for silk labour by Arasi (forthcoming). Education is also responsible for a wave of technological regression not requiring child labour in loom work). 'Education is atrophying the supply of labour' said a Silk Merchant.

\section{CREATIVE DESTRUCTION AND JOBLESS GROWTH?}

${ }^{64}$ Corbridge et al forthcoming (British Academy paper) 
For at least the first decade of the $21^{\text {st }}$ century, India's liberalisation has been associated with jobless growth, a general feature of registered formal economy. Some analysts see this seeming paradox of growth as being resolved by the recorded expansion of livelihoods in the informal economy. ${ }^{65}$ But the town of Arni is generating jobless growth in the informal economy.

Between the contradictory forces of proliferation of new forms of petty production, versus labour displacement, versus the exit of family labour, versus the integration of general wage labour in family firms and specialist wage labour in bigger firms, the net balance is an acute labour shortage at all skill levels and in all sectors of the informal economy. We have seen that this drives three kinds of change in the labour process: i) mechanisation and labour displacement (e.g. rice mills); ii) feminisation in a new increase in homeworking e.g. tailors and silk; iii) in-migration from North India (e.g. the hotel/catering industry).

What has enabled the $21^{\text {st }}$ century exodus of family labour?

\section{INNOVATION IN EDUCATION}

In reviewing macro-economic educational endowments and total factor productivity, the development economist Frances Stewart found that education does not so much affect productivity directly through the labour force. Rather productivity was affected by education indirectly through improvements in capabilities to absorb technology, particularly in access to infrastructure, finance and skilled work - and in the education needed for the two-way process of influence between commercial firms and state regulative policy. (Heyer, Fitzgerald and Thorp, 2012, p6).

In the $21^{\text {st }}$ century, education in Arni follows the pattern of Stewart's reasoning, being significant not so much for innovation per se as for the dynamo of change it releases within the town. The key to upward mobility is not seen as being informal innovation. Upward mobility requires exit, and education and competence in English are the key credentials for upward mobility and several kinds of exit. First, from agriculture. Spurred by water scarcities, adverse price structures and labour scarcity (the impact of NREGA), the flight from agriculture fuels a rush of land sales to non-local real estate speculators and mineral water companies. Second, from Arni itself. Spurred by the desire to

\footnotetext{
${ }^{65}$ A Sinha 2007 in BHW and Sinha Trade Liberalisation and India's Informal Economy OUP
} 
escape the parochialism and patriarchal authority relations of the family firm, people embark on daily commuting as well as seasonal and permanent migration.

'Arni is becoming an education hub'. 'Education is using land to take the place of land'. 'The knowledge economy is an extractive industry.' 'The state encourages education but has effectively wrecked it ${ }^{, 66}$

In the $21^{\text {st }}$ century a massive college education cluster has appeared on a tract of dry-land to the north of town, while25 pre-school nurseries , and about 100 new private English-medium schools have been established in the Arni region. ${ }^{67}$ The town has transformed itself, in an unprecedented way and at great speed, into an education hub. This is a new and non-trivial sector in the local economy. Everyone we interviewed - poor and rich, female and male, dalit and forward caste - had education as their central concern and was aware of the rapid changes. More a compulsion than a demand, this transformation in social aspirations took place at a time when the public education system in Tamil was embroiled in a politics of non-expansion. Whether deliberately intended to incentivise private education or not, this has reinforced local pressure for alternative private English schooling.

Private schools ('mostly big businessmen's playthings' a teacher explained) are formally registered, regulated and state-inspected. But this process is flawed and vulnerable to informal practices such as low and individualised pay, capitation fees (bribes for entry), unregulated teaching standards, even the corruption of examinations. The underfunded state system acts as a social safety net when it receives drop-outs from the private system.

But there is another aspect to informality in education.

For those children educated in Tamil in the state system, and for some in private schools in Arni, there is also a large and growing informal economy of private tuition. Whereas in 2005-, there were 50-60 private tuition centres, by 2012 there were well over 100 . These were mostly manned by fresh graduates, often women or retired teachers, with classes ranging from 15 to 20 at the low end, to 200 at the extreme high end. Regular state teachers are not allowed to do this

\footnotetext{
${ }^{66} 2012$ interview with a group of state high school teachers.

${ }^{67}$ Not to mention the displacement of demand through long distance migration to private boarding schools.
} 
(though a few break the rules ${ }^{68}$ ). Competition between these tuition centres effectively a parallel informal education system - is fierce, with more or less misleading advertisements of success crowding the advertising hoardings in the town centre. Popular subjects are the gateways to IT and engineering - 90\% of tuition centres cover physics, chemistry and maths, taught in Tamil. Only 20$30 \%$ of pupils take English which, though it is sought-after as a medium, is not taken as a subject because the discipline of English is given a low weighting in the aggregate marks.

In this way, the state government dis-incentivises the informal acquisition of the language of the national market, English. For the future labour force, this informal private tuition involves a gruelling 2-3 hours of extra study after a long day's learning (after $9.30-4.30$ at school and 2 hours of homework). ${ }^{69}$

Speaking to public sector teachers about innovation unleashed a torrent of examples, all drawn from the state system From smaller class sizes through new curricula and the prohibition of physical punishment to the introduction of Activity Based Learning, it seems that the practice of teaching is so receptive to innovation that state education most resembles a model innovation system. At the same time party politics has swung between a freeze on teacher recruitment (DMK) and the failure to allocate recruited teachers to positions (ADMK), resulting in dysfunctional class sizes, wrecking the capacity of the public system to respond to the legal requirement of $100 \%$ enrolment and forcing surplus teachers into the private and informal sectors.

We encountered one case of informal invention in education. ${ }^{70}$ For children forced to drop out for weeks at a time due to parental sickness and/or the peaked compulsions of work, the PTAs have innovatively organised evening classes to help such children to catch up. An NGO is also working with state schools in Arni to expand this initiative.

\section{THE PARADOX OF FORMAL EDUCATION AND INNOVATION}

\footnotetext{
${ }^{68}$ Unregulated fees range from Rs $2 k$ per subject to Rs $8 k$, averaging Rs $6 k$, for teaching the school syllabus, testing and correcting over the 8 month January to August semester.

${ }^{69}$ It is also a way of obtaining after school child care (Hodges, Pers Comm, 20013)

${ }^{70}$ Actually suggested in BHW with Camilla Roman 2003 On the Insecure lives of Tamil Nadu's Silk Weaving Families $=$ Frontline vol 20 no 24
} 
Many inventors and adaptive innovators have high levels of education (e.g. the self-employed/capitalist architect -engineer; rice mill automaters), and new levels of skilled engineering labour are now employed to install and maintain more technologically sophisticated machinery. But we learned from representatives of both banks and petrol stations that education contains its own paradox. Higher education which can produce high competence and the ability to manage complex (remote control) systems and IT, is essential for a corporate career. But a complex state or private corporate organisation, requires a compliant passivity of its skilled and educated employees in which local innovation and experimentation is forbidden. High educational qualifications are not by themselves indicative of a capacity to innovate.

\section{THE STATE AND INFORMAL INNOVATION}

The state is normally assumed to be inefficient and un-entrepreneurial. ${ }^{71}$ As with the case of education, so more generally, however, our discussions with the business association presidents, an Electricity Board director, the representative of Arni's lawyers, and the leader of the transport workers disclosed the existence of a constant stream of adoptive innovation. (These are listed in the separate Appendix). ${ }^{72}$ Here we focus on tendencies in the more or less circumstantial evidence we gathered in 2012 that reveal i) the ways in which formal state policy affects the informal economy, ii) how the informalisation of the state affects the informal economy, ${ }^{73}$ iii) how innovation takes place in and around the 'informalised state' and finally iv) the question of how the state regulates the informal economy - formally and informally.

1. How formal state policy affects the informal economy. First, it may indirectly protect the informal economy. For example, formal import controls have been imposed protecting Indian silk yarn, and the silk fabric industry dependent on it, from Chinese competition; similarly state subsidies and incentives to schoolgoers incentivise private informal tuition. Secondly it provides indispensible hard infrastructure (transport and communications) and soft infrastructure (schooling) for the informal economy. Third, it can destroy elements of the

\footnotetext{
${ }^{71}$ References to economics texts in particular

${ }^{72}$ http://www.southasia.ox.ac.uk/resources-greenhouse-gases-technology-and-iobs-indias-informaleconomy-case-rice

${ }^{73}$ And vice versa - to be developed. In half-formulated, half-implemented administrative procedures (for example, in the acquisition of land, building occupation permits) multiple procedures are mandatory- only one or two of them are followed and the rest left open to informal interpretation. The constitution of jurisdictions is also informalised in such ways (Champaka, Pers. Comm. 2013)
} 
informal economy - as when road widening and tarmacking over the 'central business district' frontages removed the sites for dalit fruit and vegetable, flowers and street food selling. Fourth, it may place an economic safety net under it - with NREGA which in the Arni region provides 100 days of work during seasons of peak competition as well as during slack times. Fifth, it may passively tolerate the informal economy - as inside the Municipal; market. While the state has policies covering the informal economy, it has no coherent development project for it.

2. How the informalisation of the state affects the informal economy. When the state operates through informal practices or parallel institutions, then informal economic practices are governed by non-state-legitimised forms of authority. For example politicians may regulate the conduct of private schools or may prevent dalits from exercising rights to their municipal housing, even when they fulfil the eligibility conditions. 'What an irony that the municipality doesn't implement its own laws', declared a sanitary worker unable to secure housing in retirement despite being eligible. The exercise of private status and private interests in selectively implemented state interventions has produced a large literature on the nexus of private and public economic power and the role of politics in reproducing intermediate classes. ${ }^{74}$ But it also has effects on the conditions of reproduction of the informal labour force.

3. How innovation takes place in and around the informalised state. A case we encountered concerns the Public Works Department, which was reported to have not recruited engineers to permanent jobs since 1989. There is no alternative but for free-lance PWD engineers to build private businesses to do work that is routinely subcontracted by the state. In and around Arni some 20 such businesses, heavily dependent on state patronage, are not regulated or inspected. Qualified engineers then compete for contracts against the unqualified and unsupervised masons who carry out about a third of the construction work (state and private) in Arni.

4. How the state regulates the informal economy - formally and informally. The formal state regulation of the informal economy is by neglect of its own laws. The state regulates selectively. ${ }^{75}$ 'Provided I pay taxes, the state doesn't bother with storage, procurement'. 'It leaves big rice mills and wholesalers alone.'(a miller - this is a significant change from the nexus of interests profiting

\footnotetext{
${ }^{74}$ McCartney and Harriss-White 2000

${ }^{75}$ Despite the GIS/GPS surveillance culture of the TN government (Hodges, Pers Comm, 2013)
} 
privately from selective and partially implemented interventions in the late $20^{\text {th }}$ century - no miller then would have been able to say that the stage left them alone) 'Market forces regulate the market now' (a lorry agent). There are rules for the spacing of irrigation wells to protect the water table, but these are honoured in the breach and the spacing of wells is still fixed by divining twigs and coconuts (a pump-set seller). 'There is less regulation than in the past' (an engineer). Less state regulation may become dysfunctional for quality standards which, despite the tendencies towards de-personalisation, will then be regulated by reputation alone. On the Food Control Inspectorate: 'There is one office for the district. They will arrive by bus and check the biggest shops next to the bus stand! They are often not educated people.' (a grocer). This neglect not only allows informal regulative practices to flourish, but also fuels informal practices that parody social protection. The ad hoc character and extreme unreliability of state welfare has long been a negative predisposing condition for collective action and/or individual savings to cover misfortune - there is no change in this. People continue to work till they are too infirm - there is neither an age of retirement nor a concept of retirement in the informal economy.

Whereas in the past what was neglected was the result of careful brokering by collective political pressure mediated through bribery by business associations $^{76}$, now the evidence points to a severe lack of state capacity and under-provision of many services (as in the example of refuse collection, below).

Turning to informal state regulation of the informal economy, we find that it is done by threat, pre-emption, interference and bribery. On threat, the laws designed to regulate big retail and FDI are already having a shadow impact in the informal economy, where a compressed process of imitation of a form of retailing that has not yet arrived is introducing much change in the retail food economy. Hitherto it has relied on a local culture of modernity involving deep social embedding (through loans, a personal clientele, leeway for negotiation (haggling) and variable quality) the changing nature of the purchases made by cash-strapped yet discriminating consumers. Pending the 'earthquake' - the

\footnotetext{
${ }^{76}$ Bribery is theorised as the privatisation of or creation of a market in public resources by officials (patrons) charging citizens (clients) (Krueger 1974, Wade 1984). In earlier field research, collective bribery was found to be initiated by business associations and powerful 'clients' to speed access to resources (licences, infrastructure), to waive obligations to the state (tax), to avoid disciplinary regulation (movement of goods, safety, labour rights etc) to delay or subvert the implementation of market regulation (packaging, transparent price formation, site, in a reversal of the orthodox theory's role of patron and client (White and Harriss-White, 1996). Clearly both balances of power between the state and capital are possible.
} 
arrival of big retail and supermarkets - the crowded sector of small grocers already faces competition via branding and TV advertisements, discounts and cross-pricing, and the deliberate creation of conditions conducive to impulsebuying. In anticipation of future regulation two grocery shops have already computerised their receipts, stock and accounts. The image consistent with examples on TV and cinema allows a modern impersonalised fixed-price marketing in which chicanery with ('900 grams dressed up as a kg') is still possible.

On interference, it is police rather than check-post guards who now regulate freight, for example. The regulative principle has shifted from a concern with the nature of the load and its degree of over-weight to the state of repair of the vehicle. States of transgression which lorry men feel are often quite minor and arbitrary are (privately) fined.

Regulative deficits (which may be caused by deliberate capture, or by lack of staff or equipment (transport, computers)) are reinforced by the prevailing ideology of market efficiency to encourage the informal economy by neglect. Yet we have evidence that the state is capable of being innovative as well as efficient. Informal contriving to protect state practices from public scrutiny achieve long-run 'efficiency', at the expense of costly transparency. Collective responsibility for constant changes in state practices to propitiate informal interests is also an 'efficient' response for the officials involved. ${ }^{77}$

\section{THE STATE AND NATURE}

\section{THE NON-ADOPTION OF INNOVATION - THE CASE OF THE SOLID WASTE ECONOMY}

All economic activity produces solid, liquid and gaseous waste. Our research examined waste water as an externality and the GHG implications of water lifting and use; we measured compost as an input, but we have not measured physical waste. It is important to record the remarkable lack of innovation in relation to waste when new, effective technologies exist. ${ }^{78}$

While residents are fastidious about waste in domestic space, in Arni there is no public consciousness about waste outside. 'The town is sinking in garbage. Noone cares about clean streets' (sanitary worker). The size of the municipal

\footnotetext{
${ }^{77}$ Champaka, Pers. Comm. 2013

${ }^{78}$ www.exnora.org
} 
sanitary labour force with its primitive trucks and equipment has remained unchanged over two decades in which solid and liquid waste has multiplied impressively (by a factor of five, some respondents thought). Sanitary workers' pay has been computerised but bank opening hours coincide with their shifts, which makes access very awkward for the dalit workers we interviewed to obtain cash to buy food, while the fact that they do have access is a symbolically polluting 'menace' to other customers. The sanitary labour force feels that nobody cares about them. The under-provision of municipal cleaning and refuse collection then incentivises a big sector of the informal economy: moonlighting; the hiring of private services within neighbourhoods; a roving circuit of tribal irular waste pickers; a thriving informal recycling business for metal, plastic, card and glass organised in Arni through Chennai by Muslims; and every day a field day for pigs and rats.

\section{NEW SCALES OF ENVIRONMENTAL PREDATION}

Like everywhere else, the town is heavily and increasingly dependent on energy from fossil fuel. Competition to control energy is conducted outside the arena of the town. The number of petrol stations doubled to 12 between 2007 and 2012; demand for diesel and petrol tripled and continues to rise, currently being reckoned to average 300 tonnes per station per week. Fuel is not only used for lorries and cars (neither of which can negotiate the central maze of narrow alleys);in the region in and around Arni motorbike ownership is expanding at an expert-estimated rate of 1,000 per month, while demand for diesel power generators is rocketing to substitute for (and complement) the deteriorating electricity supply.

The bourgeois western suburb is said to be mining the water table as unsustainably as if paddy were being cultivated there. The appetite of the fully automated rice mill paddy driers requires wood as well as husk for firing - up to 30-50 tonnes per month per rice mill. Some wood comes from casuarina farms in a radius of $50 \mathrm{~km}$ from the town but some is hacked from common land ('I know this is destructive' said an innovating miller). 'Wood cutting' is a further serious problem for the construction industry; for which sand is also mined illegally from the bed of the now permanently dry Palar river. Over wide tracts of land, agricultural topsoil is also lifted to provide clay for bricks.

Much of this activity is not just informal but illegal. None of this depredation appears to be regulated in practice by the state. 


\section{THE SOCIAL STRUCTURE OF INFORMAL INNOVATION}

Social institutions combine to form a structure which for new institutional economists is a constraint on (profit-maximising) activity. For old institutionalists it makes economic activity possible in the first place; for the 'social structure of accumulation' school it is a matrix stabilising capitalist accumulation and controlling conflict; for Marxist institutionalists it contains forms of economic authority which detract from class formation. All these approaches differ in respect of the institutions considered to be indispensible, some arguing that this is an empirical question, others using the circuits of production and re-production as a guide to what is most important ${ }^{79}$, other using ideas of dominance and prominence, or the concept of pre-capitalist institutional 'outliers'. In the absence of anything resembling a formal innovation system in the informal economy, the questions at issue here are empirical ones: which institutions nurture informal innovation and which form obstacles? Do they form a structure? This tentative attempt to answer them from a pilot field project is naturally contestable. Here we tie the evidence from the case material into a higher order narrative.

Over and above the threats to, and transformations of, the family firm (working as self-employed, with or without other family members and wage workers), and the regulative activity of the state, both of which have been handled above, three other kinds of institution stand out for the frequency with which they were mentioned: education, banks and business associations (the latter is hardly surprising since we interviewed their presidents). All are formally registered but they affect informal innovation. It was also clear that informal institutions of identity and gender matter to agency and innovation and we will link the two kind of institution in discussing education here.

Institutions of education are diverse ecosystem involving state, registered private and informal private ownership (tuition centres, apprenticeships, learning by doing, absorbing media messages etc). A high level of formal education by itself does not predispose individuals towards innovation but it

\footnotetext{
${ }^{79}$ E. O. Wright's 'predisposing factors' for innovative risk taking in worker managed firms for instance include credit markets (subsidised interest); stable income flows to labour; associational democratic governance; risk pooling; geographical anchors; and the known existence of technologies lowering diseconomies of small scale.
} 
facilitates the evaluation of information (as in the media) and access to supportive institutions (like banks). 'Arni has increasingly educated people who read adverts, watch TV and are influenced by the media' said the Chair of the Chamber of Commerce. Education and/or competence in an informal knowledge base (e.g. weaving, electrical repair) provide the continuity that enables the adoption of new practices and other kinds of agency in which material technology and behavioural norms are transformed. Lack of these capabilities hampers innovative agency.

Education however is deeply embedded in institutions of identity and their intersection affects agency and innovation. While women are well represented among classes of workers enduring chronically oppressive conditions, and have entered the labour market as home-workers, no woman was mentioned as an entrepreneur. Educated girls and women aspire to salaried jobs, an educated groom and reduced dowries. Modestly educated dalits work in occupations not requiring their education - fruit and veg, sanitation and recycling, portering, 'rooftop work', blacksmithing, lorry driving and lately informal finance. Though one dalit is the administrator of Arni's municipal bureaucracy and another is a high-ranking teacher, the well-known role models for dalits are three illegal moneylenders with large houses, compounds and swimming pools (an innovation in Arni) whose financial careers emerged from portering and fruit and vegetable selling and are owed to street wisdom rather than formal education. ${ }^{80}$. Other Dalit aspirations for 'exit' are different from those mentioned by the 'purer' castes: the police, the army, chauffeuring. For the minorities, Muslims and Christians, new reservations, each at 3.5\%, have been carved out in state employment. Muslim children are educated in Urdu until $6^{\text {th }}$ standard, after which they go to government Tamil schools where they are reported 'not always to perform well'. Muslim girls are also starting to obtain education but 'do not transform it into work afterwards' (a teacher). The lower status identity groups, in encountering social obstacles to the exercise of agency, experience formal education as necessary but far from sufficient.

The aspirations unleashed through education and often thwarted in the marketplace are not only expressed through changes in norms and economic mobility, but also through changes in motive and behaviour. Although profit and a higher standard of living are reported as proof of the benefits of adopting new products and processes, other less obviously economic motives such as

\footnotetext{
${ }^{80}$ They are said to lend at $5-20 \%$ per week and occasionally $10 \%$ per day.
} 
collegiality, the expression of social status and the desire to nurture talent in others are evident when they clash with profit and still prevail. ${ }^{81}$

Banks and finance: The effects of the influx of formally registered national banks can hardly be overestimated. First they encourage innovation in new scales of technology, with subsidised loans encouraging capital bias, which in turn requires high rates of capacity utilisation. Banks also allow working capital loans for pure commerce (forbidden until the end of the $20^{\text {th }}$ century). There is no monitoring of virement or onwards lending into the informal money markets. 'As long as we re-pay the instalments the bank doesn't interfere at all.'

By virtue of their collateral requirements (title deeds, etc) banks may play a role in formalising the informal economy along the lines advocated so influentially by de Soto $(2000)^{82}$. Loans for education and housing have rapidly increased in size and frequency. Formal property may secure (multiple) loans from (multiple) formal accounts that are subsequently invested in the informal economy or lent onwards to others. These are impossible for banks to monitor (bank manager). Title may be vested in a collective (the family) under the customary laws embedded in the constitution, and hard to associate exclusively with an individual. And 'there have been problems with duplicate (forged) title deeds in Arni'. Certain banks do not require collateral to lend to some occupation groups. Tailors mentioned their ease of access to formal loans which had been altogether denied them ten years earlier. Dalit sanitary workers in receipt of computerised salary transfers may be awarded loans of up to 10 times their salary and are accumulating formal debt for the first time ever. ${ }^{83}$ Yet the new banks are far from routing the big informal financiers in Arni who remain businessmen (traders and agents), landlords and 'finance corporations' (in which a group of savers, including government employees, invest).

Innovation requires risk-taking. For electricians and construction workers this risk may be physical, but for the most part it is financial. We have no direct evidence about the equivalent in the informal economy of venture capital but, since no-one mentioned it, conclude that lack of it is a constraint on disruptive innovation. (As already mentioned, the scaling up of the electricians' invention has been taken over by a large registered company in Bangalore). Innovation through adoption and through the exercise of agency is far less risky in money

\footnotetext{
${ }^{81}$ Electricians, carpenters

${ }^{82}$ Soto, H. de, 2000, The Mystery of Capital, Basic Books Perseus Books Group

${ }^{83}$ up to Rs 1 lakh Rs 1-2k is reported to be a usual outstanding amount for dalit sanitary workers.
} 
terms. Nonetheless, risk does permeate the informal economy. 'Half the town is saving against shocks' (Chamber of Commerce). Sickness, marriage alliances (despite the downward drift and increasing optionality of dowries), and private school and college education are as 'shocking' to the budget of a small firm as weather related downturns or business losses. For shock-absorption purposes, bank interest is not high enough to compete with returns from property and gold, which can be cashed or mortgaged easily in the town. In response to the demand for gold, a big jewellery-company from Chennai is setting up in the town. And yet, as with informal money-lending, the biggest savers are widely said to be government officials with the least shock-prone work conditions and contracts.

Business associations: beyond the state's reach informal economic activity is regulated either as though the law were being enforced, ${ }^{84}$ or through decisions of business associations. These organisations span the entire spectrum from the formal and nationally federated to the local and non-registered. Basile (2013) studied them closely in $1997 .{ }^{85}$ She sees caste as a crucial element in a corporatist system of economic regulation in which the ideology of caste (defined as a hierarchy of social status associated increasingly loosely with occupations), is secularised and increasingly internally differentiated, while the institutions of caste move from the domain of culture to that of the economy and are more or less mapped onto business associations. These are 'manifestations of the social order': defining behaviour, co-opting members across class and thwarting the development of class consciousness. Their regulative roles may include screening entry, apprenticeship, defining contractual measures and types, credit, price control in the 'market' especially for labour and derived markets such as portering and transport ${ }^{86}$, working conditions, the guarantee of livelihoods, mobilisation to compensate for accidents and premature death, poverty and social distress. Basile stresses the importance of the state in business association activity: the needs to limit the state's intrusiveness (e.g.

\footnotetext{
${ }^{84}$ Olsen, W.K., and J. Morgan. "Institutional Change From Within the Informal Sector in Indian Rural Labour Relations." International Review of Sociology 20, no. 3(2010) : 535-555.

${ }^{85}$ Basile uses the lens of Gramsci's theory of hegemony - in which the economic interests of capitalism use non-economic, political and cultural means to co-opt subaltern classes.

${ }^{86}$ Arni's silk association has a long history of state-connived containment of informal wages for weavers.
} 
from the Labour Act; the Packaging of Commodities Act and VAT) ${ }^{87}$, to protect members from the police, to appeal against discrimination, while campaigning (often using bribes) for preferment and for infrastructure, for social rights and contracts. Two questions arise. How have the business associations themselves innovated since the 1997 research; and what role do the trade associations play in informal innovation?

Many associations exist reactively, spurred into action when threatened by the state or needed by members. Only 7 or 8 of the total of 67 have real clout ${ }^{88}$ enhanced by federation and political influence at ministerial level. ${ }^{89} \mathrm{But}$ federation is one innovation that has gathered strength over the last 15 years in Arni. A second is business association support for informal training and the provision of accreditation for skills, a human 'collateral' which in turn permits the development of de-personalised transactions and migration for work. A third is the circulation of trade information, useful for the adoption of innovations from elsewhere. A fourth is the cosmopolitanisation of membership, such that the alignment between caste and trade associations is increasingly weak and acquired skill replaces ascribed merit.

In the process of informal innovation we found sharp contrasts between on the one hand, the oppressive conditions of wage/salaried workers (e.g. for transport workers: delayed payments, partial payments, refusal to renegotiate fixed wages, refusal to employ on permanent contract etc) which are not conductive to innovation; and, on the other, collegial support for invention, adaptive innovation and adoption on the part of petty artisans and small capitalist firms achieved not only through trade associations but also commercial contacts and access to banks.

So all forms of knowledge and education are preconditions for instances of all types of innovation. Yet, despite the town's being a 'low-caste place', it is clear that being a dalit, belonging to a religious minority and being a woman confine work possibilities for roughly two thirds of its population to positions where it is

\footnotetext{
${ }^{87}$ Requiring published maximum retail price indication, lists of inventory, certified weights and measures and quality control in retail, none of which was being observed in Arni, which was resolved (conceded by the state) by an agreement for incremental and delayed implementation.

${ }^{88}$ including those for rice, silk cloth, groceries, gold, the Red Cross (reflecting human rights impulses in town), the Lions, Rotary and the chamber of commerce.

${ }^{89}$ Achievements include a reduction of power-cuts for rice mills and an agreement to let women enter tailoring.
} 
much harder to innovate in the informal market place. ${ }^{90}$ And the combination of education, banks and business associations do not yet form a coherent structure of innovation. The equivalent in the informal economy of the innovation system modelled in science and technology studies spans the bounds of formal and informal regulation in idiosyncratic ways and seems to operate with few interlinkages - even informal ones. Alternatively laws, regulations and administrative procedures that can be amorphous or over-specified interact to trigger innovation in ways that have not been traced here. Further research on the social determinants of individual economic agency would be valuable.

\section{CONCLUSION}

Is the informal economy an obstacle to innovation? Pudumai - the Tamil word for innovation - means miracle as well as modern. There can be no doubting the miracles of individual resourcefulness showcased in this essay. While rural people are the poorest educated and while many ambitious young people leave Arni, those who remain are not detached from the growth process. India's growth, whether at 5 or at 9 per cent, is translated into a fast-paced engagement with innovation and institutional churning, and innovation is a precondition for growth.

What kinds of innovation? While most Indian enterprises are in the informal economy it does not follow that the informal economy is the abode of enterprise. Enterprise and innovation are both fuzzy concepts, defined in many ways. But however these concepts are defined, the fieldwork reported here revealed examples of i) Schumpeterian entrepreneurship - the inventive bridging factors of production to create new production methods and technologies, in commodification, in cost-competition, products and forms of organisation; ii) adaptive technological and organisational innovation; iii) the transfer and diffusion of known technologies, processes, products and organisation into new social contexts, iv) the diffusion of knowledge through new roles for the media and education, new images just as capable of transforming local production relations as of feeding new social and economic aspirations; v) other motives for innovation than the realisation of social aspiration and status (not only profit, livelihood and the standard of living but also the problem-solving mentality celebrated by Jugaad, the need to respond to selective state failures in provision, regulation and enforcement, pre-emptive

\footnotetext{
${ }^{90}$ Muslims and Christians are about $10 \%$ of the population, Dalits about $15 \%$, women $50 \%$.
} 
reactions to threatened change, collegiality/collective advancement and nurture); vi) innovation and agency by labour and for labour as well as by and for capital; vii) radical disruptive innovation (the NEFT of banks) as well as incremental innovation (cases of informal invention are all incremental); viii) the under-development of innovation rents permitting rapid copying and extensive multipliers and spill-overs with further impacts on the interface between the formal and informal economy and the state; ix) exit and exodus as innovation; $x$ ) creative destruction (of child labour, work, technologies, cultures and relations of of exchange, products, forms of organisation, and forms of finance); xi) the continuity of the informally acquired knowledge base as vital to the engagement with novelty. Far removed from the stereotype of 'rural idiocy ${ }^{91}$ and conservatism, these are all evidence of the abundant social and economic resources and relations - and of the range of motivations that might be put to work in a low $\mathrm{C}$ transition.

What roles are played by informal institutions? Key institutions which regulate innovation in the informal economy, incentivising or discouraging novel practices, have been found to include the family-firm, social identity, education (formal and informal), banks (formal) and finance, and more or less well registered and active business associations. The exchange with the state, itself fully capable of innovation, includes the redefinition of the boundary between formal and informal activity (education, energy), selective enforcement (licences), tolerance of informal formalisation (certification) and neglect (in turn the product variously of capture, or of the scarcity of personnel and/or equipment). The informal equivalent of the research lab is the individual guinea-pig in society and the business association. Risk is borne by the innovator, buttressed by savings in which gold still plays an important role. Business associations/guilds grounded in caste are gate-keepers for entry as well as screeners of innovation. In a politics of representation, regulation and mediation, this set of corporatist interests negotiates collegiality within a sector just as it controls the erosion of social barriers to entry. Formal education most resembles an innovation system, but one where formal and informal knowledge institutions intertwine. While some kinds of innovation need training, skills and education, and while English is a passport to economic mobility, education generates its own paradoxes. Much knowledge is learned on the job in various ways - and through self-skilling. People with low education are not

\footnotetext{
${ }^{91}$ For Marx who coined the phrase, it meant isolation, ignorance and an inability to co-operate.
} 
uninnovative. ${ }^{92}$ People with high education are not necessarily given to innovation or required to innovate inside complex organisations.

Is there an informal structure of innovation resembling an innovation system? The meshing of formal and informal institutions counters the idea that they are discrete epistemological universes (Gupta, 1999) but this does not mean that the formal-informal distinction should be abandoned or that this hybrid 'ecosystem' works in a co-ordinated or systematic way or that it is immune from contradictions. Institutions serving useful roles in the structure of accumulation (gender for instance) may be barriers to agency and innovation. A coherent informal structure of innovation has yet to emerge and may never do so.

What are the implications of these findings about innovation for a new lowcarbon industrial revolution that is not yet happening at a pace appropriate to the problem? Although this is not an Indian problem but a global one, the scope of informality is distinctively Indian, and the informal economy is moving in the opposite direction to a low-carbon economy. For every single example of energy efficiency (notably the three to two phase switching here) there are many more requiring energy from fossil fuel or the un-sustainable plundering of local natural resources.

That the direction of travel is negative is not the product of the informal economy per se. It reflects the entire Post-Independence thrust of industrialisation. A low carbon economy is a radical novelty as yet far from being accepted discursively as 'development'. Indeed advocates of development often resist the idea that carbon emissions must be reduced. Appropriate and superior technology exists that can reduce carbon emissions, obstructed not by patent law but if at all by licensing. It is currently designed for a scale above that of the small town informal economy - one challenge is therefore to scaledown (size of new technology) while scaling-up (industrial output). However, the difference in capital intensity between the bazaar and current low $\mathrm{C}$ innovation is further exacerbated because many new renewable energy technologies have high capital costs relative to variable ('running') costs - and up-front investment costs are unattractive to banks.

\footnotetext{
${ }^{92}$ Indeed Anil Gupta has referred to the poor as knowledge rich and devoted his life to recording the vitality of innovations by poor people in agriculture and rural development (1999, Science, Sustainability and Social Purpose http://www.hks.harvard.edu/sustsci/ists/TWAS 0202/gupta 300199.pdf).
} 
But national policy for climate change implies a confrontation with technological / innovation systems already constructed by specific political interests, vested in existing arrangements, path dependent and dense in their demands for fossil fuel. This is reflected not in policy statements - for India is committed discursively to solar energy - but in a knot of poorly co-ordinated regulations: subsidies, tariffs, practices of bank lending, profit extraction and asset ownership, which together lock India into the fossil fuel usage that dominates public support and infrastructure subsidies. Low carbon development is currently conceived as the product of a research, development and diffusion process which cannot do without planning and is assumed to be formally stateregulated..$^{93}$ (Formal) market forces alone cannot create the new institutions and destroy the old ones for the new industrial revolution.

In the policy literature on informality the institutions of property rights and finance have pride of place is enjoyed by ${ }^{94}$ But property rights were rarely mentioned to us as problems in the informal economy: the impossibility of protecting innovation rents dynamises rapid diffusion. Even if protected by patents / IP, attempts will be made to reverse-engineer products and technology in the informal economy. Lack of access to formal investment finance is indeed an impediment to those lacking formal titles to property. But bank credit does not always require collateral ${ }^{95}$ and once obtained it is easily vired into the informal economy. The scale of capital requirements can also be an impediment to innovation, where it tends at present to be small-scale and labour-intensive, but there is evidence of novel forms of collective organisation to scale up collective venture capital. ${ }^{96}$ Lack of knowledge is an obstacle too, but there is an insatiable thirst for knowledge and evidence of informal institutions which provide it. The energy sector is where low carbon transitions must start, and some of the liveliest capabilities are to be found among informally qualified electricians and engineers. The embedding of the informal economy in institutions of identity might even privilege dalits, the most socially underprivileged workers, for, despite the chronically oppressive conditions in which they work, they are expert in energy, waste and refuse.

A non-marginal change in political capabilities would be needed, however, to address the two problems of the sluggish transition to low-carbon technology

\footnotetext{
${ }^{93}$ Harriss-White, Rohra and Singh 2009 EPW

${ }^{94}$ De Soto 2000

${ }^{95}$ It may rely on collective guarantees, on reputation or on stable income flows

${ }^{96}$ Sunali Rohra, 2012 Pers Comm, see also http://www.ceew.in/blog/
} 
and the pervasive nature of India's informal economy whose innovative capabilities are not harnessed by the state, and there is no indication in our work so far how it might emerge.

Last, this study of innovation is embedded in a research project on the materiality of the economy, the waste gases from economic activity, and the prospects for a low $\mathrm{C}$ transition which negotiates the fact that most economic activity in India is in the informal economy. A new research agenda emerges from this pilot project, first and foremost to make progress in the search for a low $\mathrm{C}$ transition but also carrying important implications for other research fields:

i)the material stock and flow accounts of a small town, including its energy economy and construction sector;

ii)the waste economy and its institutions: solid, liquid and gaseous

iii) the roles of dalits in the management of solid and liquid waste and their potential as leaders in the management of gaseous waste;

iv) green innovation in the informal economy (exceptionally difficult to locate);

v) the education hub and the knowledge economy, informal knowledge and the informal economy;

vi) liberalisation, partial state intervention, fiscal non-compliance and local capitalism;

vii) the motors and effects of formalisation (the roles of banks, corporate capital and the state).

\section{ACKNOWLEDGEMENTS}

Bhw wishes to thank the following people and organisations for the opportunity of presenting the aspect of a collective research project that is reported here: 
Prof Kalpana Kannabiran and the Centre for Social Research Hyderabad, November 2012; Prof Pravin Jha and the Long Term Village Studies Conference JNU, New Delhi, November 2012, Prof Francois Combarnous, Universite Bordeaux IV, March 2013; Prof Xiaolan Fu and the TMD Centre, Oxford/Tsinghua Universities Conference on Innovation and Entrepreneurship for Inclusive and Sustainable Development (August 2013); Prof David Booth and the ClimUrb Conference, Manchester ( September 2013). She is grateful to R Champaka and to Dr Sarah Hodges for their searching comments on the early draft.

REFERENCES (to do) 
TO BUSINESS ASSOCIATION PRESIDENTS AND OTHER NOTABLE REPRESENTATIVES ABOUT INNOVATION IN THE INFORMAL ECONOMY

1. Your sector - how big -number of firms - structure -castes - immigrants

What has been the biggest change in your sector over the last $50-10$ years? A technique? A change in organisation? The structure of the sector? Something else? infrastructure? Let's choose the most important for you.

2. Where and when did it arrive? Would you say it was incremental or a big disruptive change?

3. Was it invented in Arni? Was it heard of somewhere else and transferred here? From where? By whom?

4. How was the knowledge acquired for the innovation? How did it affect work and thre social composition of the workforce? Did it have implications for womens' work? How?

5. If a worker innovated how were they involved and were they rewarded?

6. What were the most significant barriers to the innovation? Raw materials? Energy? Transport? Markets?

7. How was new technology adapted to local conditions?

8. What was needed by way of other skills - here and elsewhere? Other techniques and technologies (mobile phone)? Here and elsewhere?

9. What were the costs involved in acquiring these skills and technologies? Who covered them? How? ( private loans/government incentives/ tax breaks/ micro-finance loans?)

10. How was the innovation protected. How did it diffuse? Why?

11. Was it risky to introduce or develop? How were the risks dealt with? Did it result in failure and losses? How were they overcome? Did luck play a role?

12. Who opposed the innovation/ was there hostility? From whom? How expressed? Who lost out because of it? How and why?

13. How did the business association help at various stages? If not the business association, the caste association? The town organisations? An NGO?A political or religious organisation? Another kind of organisation outside the firm?

14. Was the government involved in any way? How? TN govt / parastatals /local municipality /? Did licences and vigilance play a role at all/ ? Where some policies helpful and others not working in opposite directions? If so what?

15. What role did banks and bog companies play?

16. Were local private colleges and training facilities involved? How? Any informal institutions of learning?

17. How has the change affected the structure of your sector? \profits? Use of profits? Has it made entry more difficult?

18. Have there been further innovations that depend on the one you describe? What has been the impact on work in your sector? In the town? In the rural region?

19. Do you recall any failed innovations - ones which did not spread and were abandoned? Why do you think they failed? 
20. Are there any important questions about innovation in your sector that we haven't asked you?

21. What do you want for your children's future? 
